\title{
Phytochemical evaluation and pharmacognostic standardization of Syzygium palghatense endemic to Western Ghats
}

\author{
V. R. Snehalatha* (1) and A. R. Rasmi
}

\begin{abstract}
Background: The plants belonging to the genus Syzygium has received much attention since ancient times due to its multidimensional uses for mankind. These plants in general, reported to contain a wide array of phytomolecules with a broad spectrum of biological activities that include antihypoglycemic, antioxidant, anti-inflammatory, anticarcinogenic, and antihypertensive properties. The pharmacological potential of $S$. palghatense which is endemic to Western Ghats has not yet been investigated. The present study was intended to examine the potential benefits of the leaves and bark of S. palghatense.

Results: Morpho-anatomical studies of S. palghatense provided useful details for the identification. The pharmacological characterization of the plants shows significant results in their studied parameters. The total phenolic and flavonoid contents were higher in methanolic extracts of leaves and bark of S. palghatense. Methanolic extract of the leaves and bark have superior antioxidant capacity when compared with the chloroform, ethyl acetate, and distilled water extracts. A significant result in alpha amylase and alpha glucosidase enzyme activity was exhibited when antidiabetic study was performed.

Conclusion: The current study showed that the methanolic extract of S. palghatense leaves and bark have significant pharmacognostic properties and potential antioxidant and antidiabetic compounds. Phytochemical studies portray the presence of several biologically active secondary metabolites, including essential oil, alkaloid, glycosides, carbohydrate, tannins, reducing sugar, phenolics, and saponins, which may be the reason for its biological properties. As compared to bark, leaves of $S$. palghatense possess significant activity toward all the biological properties tested.
\end{abstract}

Keywords: Syzygium, Morpho-anatomical, Physicochemical, Antioxidant, Antidiabetic

\section{Background}

Syzygium palghatense Gamble belongs to the family Myrtaceae, endemic to Western Ghats were seen in Parambikulam Wildlife Sanctuary, which is the third largest protected area in Kerala. The sanctuary is bordered by Vazhachal forest division in the South, Chalakkudy in the West, Nelliampathy Ghats continuous to the Palghat

* Correspondence: snehagvc@gmail.com

PG and Research Department of Botany, Govt. Victoria College, Palakkad, Kerala 678001, India

\section{Springer Open}

gap on the North, and the Indhira Gandhi Wildlife Sanctuary on the East. The evergreen and shola forests in the high ranges of the Western Ghats are ideal habitats for Syzygium species with a high rate of endemism [1].

Phytochemical studies have attracted the attention of plant scientists due to the development of new and sophisticated techniques. Phytochemicals could exhibit bioactivities such as antimutagenic, anticarcinogenic, antioxidant, antimicrobial, and anti-inflammatory properties [2]. Different species of Syzygium have been 
previously investigated in several pharmacological activities such as antibacterial, antifungal, analgesic, antiinflammatory, antihypoglycemic, antioxidant, anticarcinogenic, and antihypertensive properties. These plantderived phytochemicals with therapeutic properties could be used as single therapeutic agent or as combined formulations in drug development.

Tracing the available current literature, it was found that there is no information on the pharmacological characters of S. palghatense. Therefore, the following work has been planned to examine the pharmacological and biological activities to find out the potential benefits of the plant under investigation.

\section{Methods}

\section{Plant material: collection and identification}

Leaves and bark of the $S$. palghatense were collected from Nelliyampathy region of Nemmara forest division, Palakkad, Kerala, India. The material was identified and authenticated by Dr. P. Sujanapal, Scientist, Silviculture Department, Kerala Forest Research Institute, Peechi, Thrissur and Dr. A.K. Pradeep, Assistant Professor, Department of Botany, University of Calicut. Collected samples of leaves and bark were dried under shade and powdered separately. The voucher specimen was deposited in the Calicut University Herbarium, Department of Botany, with accession number 7054.

\section{Morpho-anatomical characterization}

The shape of leaf, margin, color, and nature of bark were examined. For studying, stomatal morphology and venation pattern, paradermal sections, as well as clearing of leaf with $5 \%$ sodium hydroxide or epidermal peeling by partial maceration employing Jeffrey's maceration fluid [3] were prepared. A rotary microtome has been used to section the paraffin-embedded leaf and bark of the plant sample. The sections were 10-12 $\mu \mathrm{m}$ thick. Toluidine blue has been used to stain the sections [4].

\section{Pharmacognostic characterization Powder microscopy}

Cell structure and behavior of the leaf and bark powders were observed using standard procedures. The powder form of leaf and bark sieved, stained with safranin, mounted in glycerin, and observed under microscope $[5,6]$.

\section{Fluorescence analysis}

The powders of both leaves and bark of S. palghatense was treated with several reagents such as acetone, acetonitrile, methanol, and distilled water. It was further observed under UV and visible light (254 $\mathrm{nm}$ and $366 \mathrm{~nm}$ ) to note the color produced after treatment and fluorescence character were studied $[7,8]$.

\section{Physicochemical characterization}

Various physicochemical parameters (water-soluble extractive, alcohol-soluble extractive, petroleum ether extractive, ethyl acetate-soluble extractive, crude fiber, vitamin $A$, vitamin $C$, minerals, heavy metals, total ash, acid insoluble ash, water-soluble ash, and sulphated ash) were investigated on the powdered sample of both leaves and bark of S. palghatense [9-15].

\section{Phytochemical characterization Extraction}

The collected leaves and bark of S. palghatense were separately shade dried and powdered. Soxhlet extraction method was used to extract leaves and bark of the plant sample and were performed using different solvents including, chloroform, ethyl acetate, methanol, and distilled water. After the extraction, the solvent was evaporated using a rotary evaporator [16]. The total extractive values were calculated on dry weight basis by the following formula:

$$
\begin{aligned}
\text { Percentage extractive value (yield } \%) & \text { Weight of dry extract } \\
= & \frac{\text { Weight of the plant sample taken for extraction }}{\text { plat }} \times 100
\end{aligned}
$$

The dried extracts were stored in refrigerator for further studies.

\section{Qualitative phytochemical analysis}

Preliminary phytochemical investigations for secondary metabolites were carried out using standard procedures. The metabolites tested were alkaloids, flavonoids, glycosides, saponins, carbohydrate, tannins, reducing sugar, starch, phenolics, anthraquinone, fats and oils, essential oils, proteins, aminoacids, steroids, and coumarin [16-22].

\section{Quantitative phytochemical analysis Alkaloids}

Alkaloids in a plant sample were measured quantitatively $[17,23]$. In a $250 \mathrm{ml}$ beaker, $2.5 \mathrm{~g}$ of the plant sample was treated with $200 \mathrm{ml}$ of $10 \%$ glacial acetic acid in ethanol and allowed to stand for $4 \mathrm{~h}$ for extraction. The extract was then concentrated in a water bath until it was reduced to $1 / 4^{\text {th }}$ of its original volume. Concentrated ammonium hydroxide solution was added drop wise till complete precipitation was achieved. The supernatant was discarded after $3 \mathrm{~h}$ of sedimentation, and the precipitate was washed with dilute ammonium hydroxide and filtered. In an oven, the residue was dried and measured. The percentage of alkaloid content in a given amount of sample was determined using the following formula, 
Percentage of alkaloid $=\frac{\text { Weight of alkaloid }}{\text { Weight of sample }} \times 100$

\section{Flavonoids}

The aluminum chloride colorimetric assay was used to determine total flavonoid content. In a $10 \mathrm{ml}$ volumetric flask, a reaction mixture of $1 \mathrm{mg} / \mathrm{ml}$ extract and $4 \mathrm{ml}$ distilled water was prepared. To the flask, $0.30 \mathrm{ml}$ of $5 \%$ sodium nitrite was treated and after $5 \mathrm{~min}, 0.3 \mathrm{ml}$ of $10 \%$ aluminum chloride was mixed. Two milliliters of $1 \mathrm{M}$ sodium hydroxide was treated and diluted to $10 \mathrm{ml}$ with distilled water after $5 \mathrm{~min}$. A set of quercetin reference standard solutions $(20,40,60,80$, and $100 \mathrm{~g})$ were prepared. An UV/Visible spectrophotometer was used to measure the absorbance of the test and standard solutions against the reagent blank at $510 \mathrm{~nm}$. The total flavonoid content of the extract was calculated as $\mu \mathrm{g} / \mathrm{mg}$ [24].

\section{Glycosides}

One milliliter extract and $1 \mathrm{ml}$ Baljet's reagent (freshly prepared $95 \mathrm{ml} \mathrm{1 \%}$ picric acid and $5 \mathrm{ml} \mathrm{10 \%} \mathrm{NaOH}$, blended immediately before use and filtered through a sintered glass funnel) are combined and allowed to stand for $1 \mathrm{~h}$. The solution was diluted with $2 \mathrm{ml}$ distilled water and mixed thoroughly. A spectrophotometer was used to measure the color intensity against a blank at $495 \mathrm{~nm}$ [25].

\section{Saponins}

Ten milligrams diosgenin was dissolved in $16 \mathrm{ml}$ methanol and $4 \mathrm{ml}$ distilled water to make a standard saponin solution. Vanillin reagent $(8 \%, 0.25 \mathrm{ml})$ was applied to the aliquots for each tube, and sulfuric acid $(72 \% \mathrm{v} / \mathrm{v}, 2.5$ $\mathrm{ml}$ ) was progressively added on the inner side of the tube wall. The solutions were thoroughly combined before being moved to a $60{ }^{\circ} \mathrm{C}$ water bath. After $10 \mathrm{~min}$ of incubation, the tubes were cooled for 3-4 $\mathrm{min}$ in an ice cold water bath. Against a reagent blank, the absorbance was measured at $544 \mathrm{~nm}$. In aqueous methanol (80\%, 0.1 $\mathrm{ml}), 0.1 \mathrm{~g}$ of freeze-dried sample was dissolved. At 544 $\mathrm{nm}, 0.25 \mathrm{ml}$ aliquot was taken for spectrophotometric determination of total saponins [26].

\section{Total carbohydrate}

One hundred milligrams of the sample was taken in a boiling tube and hydrolyzed for $2-3 \mathrm{~h}$ with $5 \mathrm{ml}$ of 2.5 $\mathrm{N} \mathrm{HCl}$ in a boiling water bath before being cooled to room temperature. Until the effervescence ceased, neutralized it with solid sodium carbonate. The volume was made up to $100 \mathrm{ml}$, centrifuged, and the supernatant was collected, and 0.2 to $1 \mathrm{ml}$ was taken for analysis. The standards were prepared by taking $0.2-1 \mathrm{ml}$ from the working standard of glucose $(10 \mathrm{mg} / 100 \mathrm{ml})$ with distilled water to make up to $1 \mathrm{ml}$. One milliliter water serves as a blank; fill the tubes with distilled water to 1 $\mathrm{ml}$, then add $4 \mathrm{ml}$ anthrone reagent and heat in a boiling water bath for 8-10 min. The glucose concentration in the sample was determined [27].

\section{Tannin}

The Folin-Ciocalteu method was used to determine the amount of tannin in the sample. The measurement of blue color produced by the reduction of phosphotungstic molybdic acid by tannin-like compounds in an alkaline medium is used to colorimetrically estimate tannins. With distilled water, $1 \mathrm{ml}$ of extract and a standard solution of tannic acid $(20-100 \mu \mathrm{g})$ were made up to $7.5 \mathrm{ml}$. After that, $0.5 \mathrm{ml}$ Folin-Ciocalteu reagent and $1 \mathrm{ml}$ sodium carbonate solution (35\%) were added. The volume was made up to $10 \mathrm{ml}$ with distilled water and the absorbance was assessed at $700 \mathrm{~nm}$ [28].

\section{Reducing sugar}

Homogenized sample (100-500 mg) was transferred to a beaker. Then, $5 \mathrm{ml}$ warm ethyl alcohol was added and mixed for 15-20 min with a glass rod. In a centrifuge tube, the supernatant was decanted. The residue was reextracted for two times with $3 \mathrm{ml}$ portion of ethyl alcohol. The supernatant was combined in a centrifuge tube, and the ethanol was evaporated on a water bath (70-80 ${ }^{\circ} \mathrm{C}$ ) until the residue was dry. The sugar was dissolved in $10 \mathrm{ml}$ distilled water. Centrifuged for $15-20 \mathrm{~min}$ at $1000-1200 \mathrm{rpm}$. Pipette the standard solutions of 0, 0.5, $1.0,1.5,2.0,2.5$, and $3.0 \mathrm{ml}$ into clean numbered test tubes. In two numbered test tubes, a $1 \mathrm{ml}$ alcohol extract of the sample was taken. Further, $3.0 \mathrm{ml}$ solution volume prepared by adding 3.0, 2.5, 2.0, 1.5, 1.0, and 0.5 $\mathrm{ml}$ distilled water to the appropriate numbered tubes. Three milliliters of alkaline dinitrosalicylic acid reagent was added. For $5 \mathrm{~min}$, all test tubes are placed in a boiling water bath. One milliliter sodium potassium tartrate solution was added to all tubes while they were still hot. The absorbance of orange red color was measured at $510 \mathrm{~nm}$ after proper mixing and cooling [29].

\section{Phenol}

The aliquot of sample was pipetted out and the volume in tube was increased to $3 \mathrm{ml}$ with distilled water. Then, $0.5 \mathrm{ml}$ Folin-Ciocalteau reagent and $2 \mathrm{ml}$ sodium bicarbonate solution (20\%) were added; the tubes were immersed in boiling water bath for $1 \mathrm{~min}$. In a spectrophotometer, the absorbance was measured at $750 \mathrm{~nm}$ after the tubes were cooled [30].

\section{In vitro antioxidant activity DPPH radical scavenging assay}

Different solvent extracts (chloroform, ethyl acetate, methanol, and distilled water) of leaves and bark of $S$. 
palghatense were tested for its scavenging activity against the stable free radical DPPH (2,2-diphenyl-1picrylhydrazyl). When DPPH is in its radical form, it has a $517 \mathrm{~nm}$ absorption band that disappears when it is reduced. Different concentrations of the sample were added to $0.375 \mathrm{ml}$ of freshly prepared DPPH solution in methanol. The volume was made up to $2 \mathrm{ml}$ with respective solvents. The absorbance of the reaction mixture was measured at $517 \mathrm{~nm}$ after $20 \mathrm{~min}$ of incubation in the dark. The percentage inhibition was calculated and concentration needed for $\mathrm{IC}_{50}$ was estimated [31].

\section{Superoxide radical scavenging assay}

Superoxide scavenging activity of the different solvent extract of the plant sample was determined by nitroblue tetrazolium (NBT) reduction method [32]. It depends on the light-induced superoxide generation by riboflavin and the corresponding reduction of NBT. Various concentrations of the plant extracts was added to the reaction mixture consisting of $0.1 \mathrm{M}$ ethylene diamine tetra acetic acid (EDTA) containing $0.3 \mathrm{mM} \mathrm{NaCN}, 0.12 \mathrm{mM}$ riboflavin, $1.5 \mathrm{mM} \mathrm{NBT}$, and $0.067 \mathrm{M}$ phosphate buffer making up the volume to a total of $3 \mathrm{ml}$. The tubes were uniformly illuminated with an incandescent lamp for $15 \mathrm{~min}$ and the optical density was measured at $560 \mathrm{~nm}$ before and after the illumination. The percentage inhibition was evaluated by comparing the absorbance values of the control and the experimental tubes [32].

\section{Hydroxyl radical scavenging activity}

Hydroxyl radical scavenging activity was measured by the competition between deoxy 2-ribose and plant extracts. The reaction mixture contained ferric chloride $(100 \mu \mathrm{M})$, EDTA $(100 \mu \mathrm{M})$, deoxy-2-ribose $(2800 \mu \mathrm{M})$, phosphate buffer $(100 \mu \mathrm{M}, \mathrm{pH} 7.4)$, hydrogen peroxide $(100 \mu \mathrm{M})$, ascorbic acid $(100 \mu \mathrm{M})$, and various volumes of sample $(2-12 \mu \mathrm{l})$ in a final volume of $1 \mathrm{ml}$. Incubated reaction mixture at $37^{\circ} \mathrm{C}$ for $1 \mathrm{~h}$. At the end of incubation, $1.5 \mathrm{ml}$ of acetic acid (20\%, pH 3.5), $0.2 \mathrm{ml}$ of sodium dodecyl sulfate (SDS, 8.1\%), and $1.5 \mathrm{ml}$ of tertiary butyl alcohol (TBA, $0.8 \%$ ) were added to $0.4 \mathrm{ml}$ of reaction mixture. After thorough mixing, the reaction mixture was incubated at $100{ }^{\circ} \mathrm{C}$ for $1 \mathrm{~h}$, and the formation of thiobarbituric acid reactive substances (TBARs) was determined using a spectrophotometric method at 532 $\mathrm{nm}$. All of the experiments were performed in triplicate, and the percentage of inhibition was determined using the following formula: Percentage of inhibition $=\left[A_{\mathrm{c}}-\right.$ $\left.A_{\mathrm{s}}\right] / A_{\mathrm{c}} \times 100 ; A_{\mathrm{c}}$ and $A_{\mathrm{s}}$ is the absorbance of control and sample respectively [33].

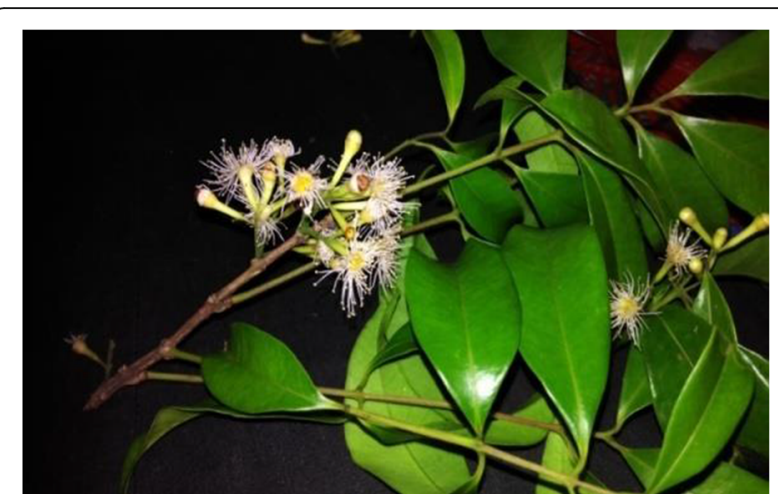

Fig. 1 Flowering twig

\section{Ferric-reducing antioxidant power assay}

The antioxidant capacity of different extracts was estimated. The method measures the ferric reducing ability (ferric-reducing antioxidant power, FRAP). When a ferric tripyridyl triazine (Fe III-TPTZ) complex is reduced to ferrous (Fe II) form at low $\mathrm{pH}$, an intense blue color with an absorption maximum at $595 \mathrm{~nm}$ is developed. FRAP reagent $(25 \mathrm{ml} 300$ $\mathrm{mmol} / \mathrm{L}$ acetate buffer, $\mathrm{pH} 3.6 ; 2.5 \mathrm{ml} 10 \mathrm{mmol} / \mathrm{L}$ TPTZ (2,4,6-tripyridyl-s-triazine) in $40 \mathrm{mmol} / \mathrm{L} \mathrm{HCl}$ and $2.5 \mathrm{ml} 20 \mathrm{mmol} / \mathrm{L} \mathrm{Fecl} \cdot 6 \mathrm{H}_{2} \mathrm{O}$ solution), prepared freshly and $900 \mu \mathrm{l}$ was mixed with different concentration of plant extract and made the volume up to $1 \mathrm{ml}$ using distilled water. The reaction system was incubated at $37{ }^{\circ} \mathrm{C}$ for $20 \mathrm{~min}$. Reading was taken against distilled water blank at the absorption maximum $595 \mathrm{~nm}$ in spectrophotometer. The percentage increase in the ferric reducing activity was then calculated [34].

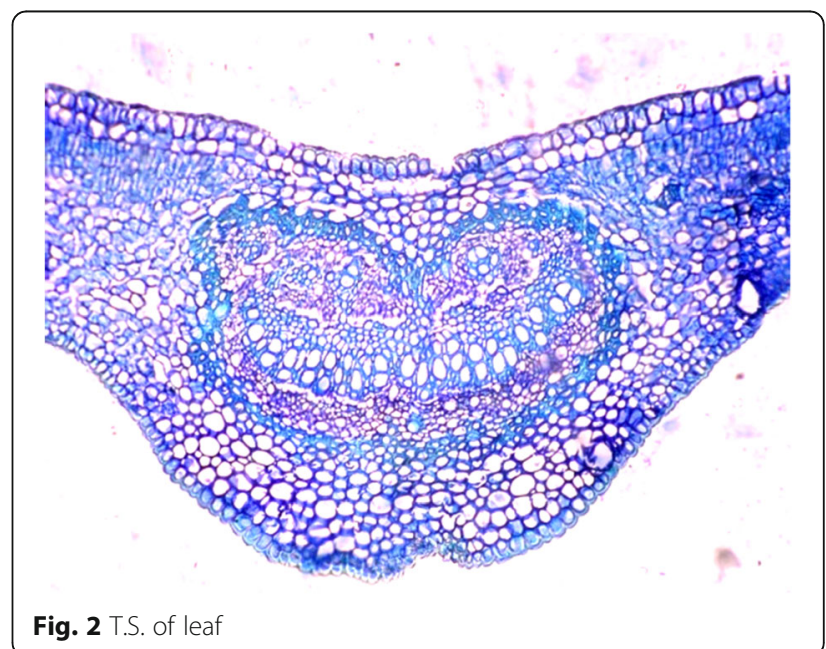




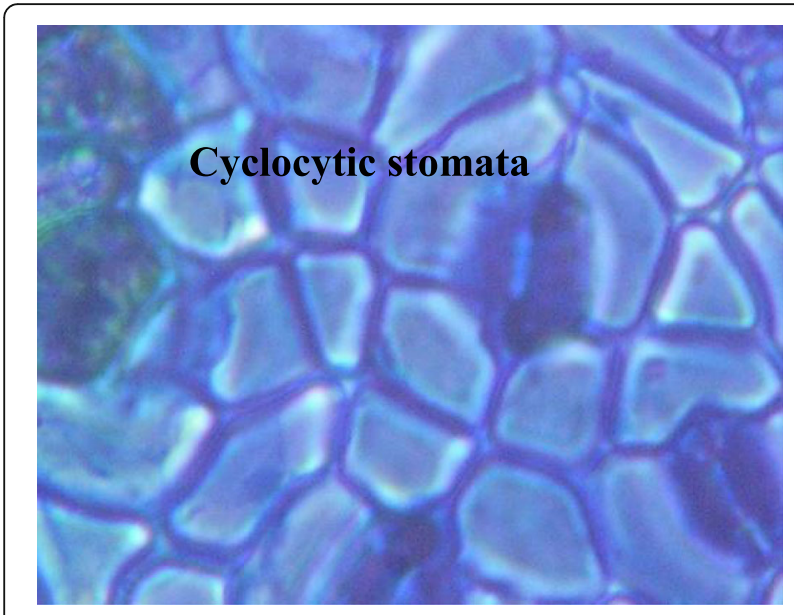

Fig. 3 Stomata

\section{Anti-diabetic activity}

Alpha amylase inhibitory assay

One percent phosphate buffer and the starch solution was prepared and incubated with $500 \mu \mathrm{l}$ enzyme ( $\alpha$-amylase) for $10 \mathrm{~min}$ at $37^{\circ} \mathrm{C}$. Then, $1 \mathrm{ml}$ of $(20,40,60,80$, and 100 $\mu \mathrm{g} / \mathrm{ml}$ ) isolated pooled fractions from methanol extract of leaves and bark of $S$. palghatense was added to the enzyme solution. Further, $2 \mathrm{M}$ of $\mathrm{NaOH}$ is applied to stop the reaction process. One milliliter of dinitro salicylic acid is mixed and the reaction is maintained in the hot water bath for $5 \mathrm{~min}$. After completion of incubation, test tubes were cooled by running tap water, and the final volume of test solution was to make up to $10 \mathrm{ml}$ using sterile distilled water and absorbance was measured at $540 \mathrm{~nm}$. Acarbose was used as a reference substance [35].

\section{Alpha glucosidase inhibitory assay}

One milligram of the $\alpha$-glucosidase enzyme (isolated from Saccharomyces cerevisiae) was suspended with 100 $\mathrm{ml}$ neutral phosphate-buffered saline buffer which contains the $200 \mathrm{mg}$ of bovine serum albumin [36]. The various concentrations $(20,40,60,80$, and $100 \mu \mathrm{g} / \mathrm{ml})$ of

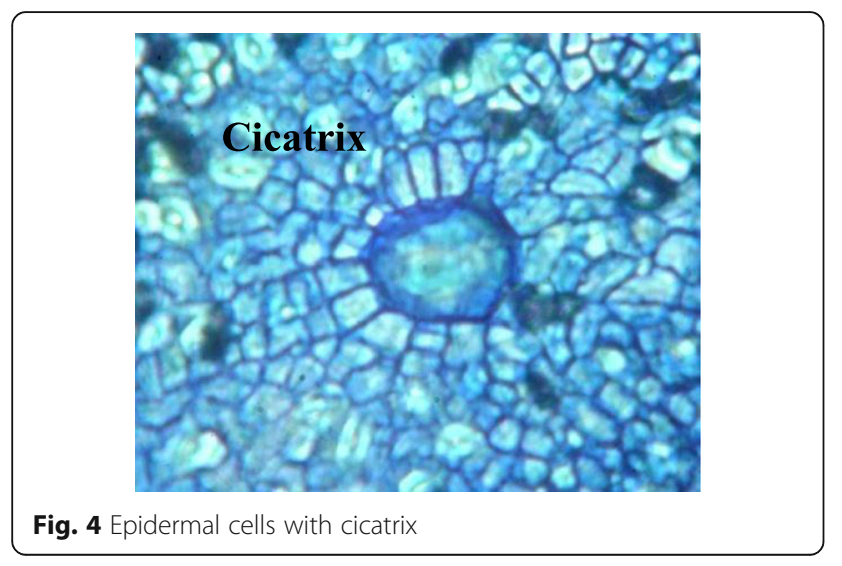

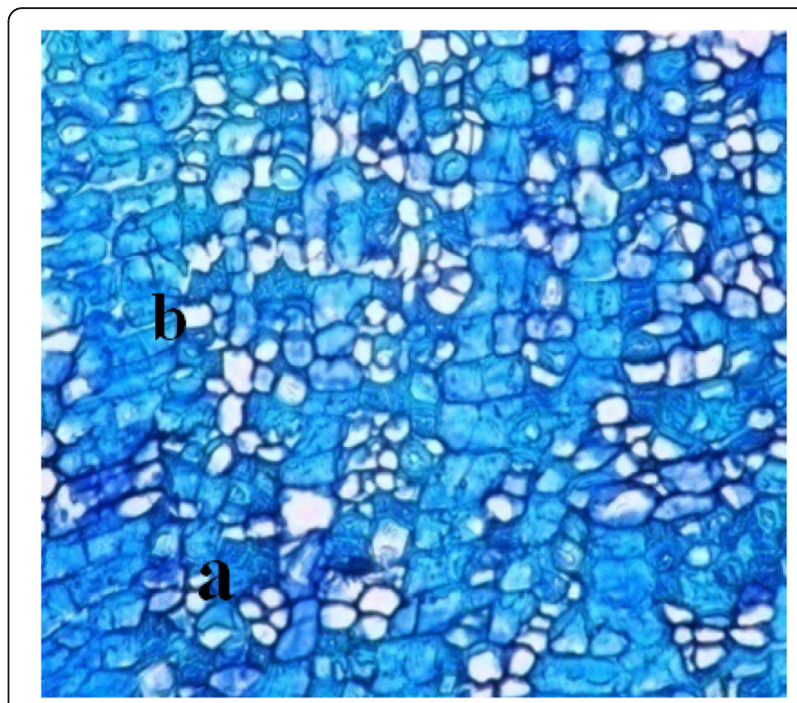

Fig. 5 T.S of bark showing a collapsed phloem zone with $\mathbf{b}$ dilated phloem rays

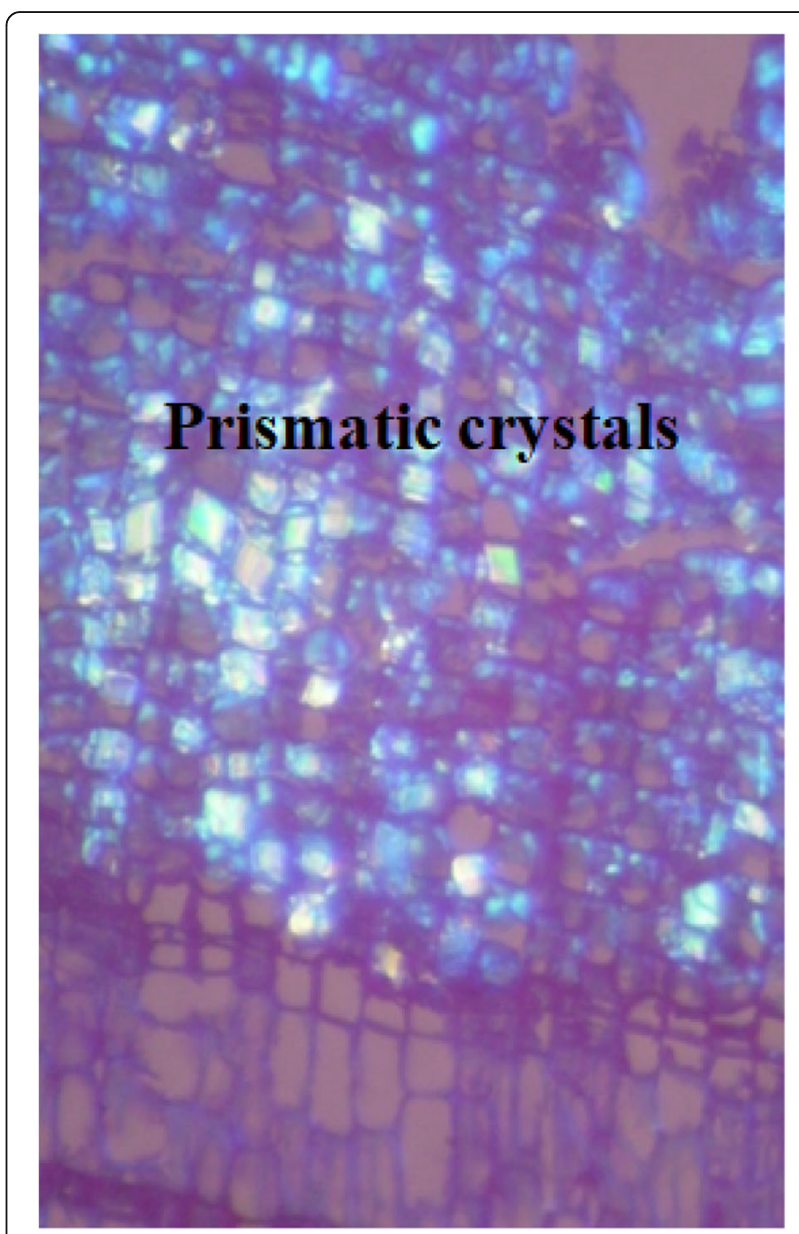

Fig. 6 Phelloderm with prismatic crystals 


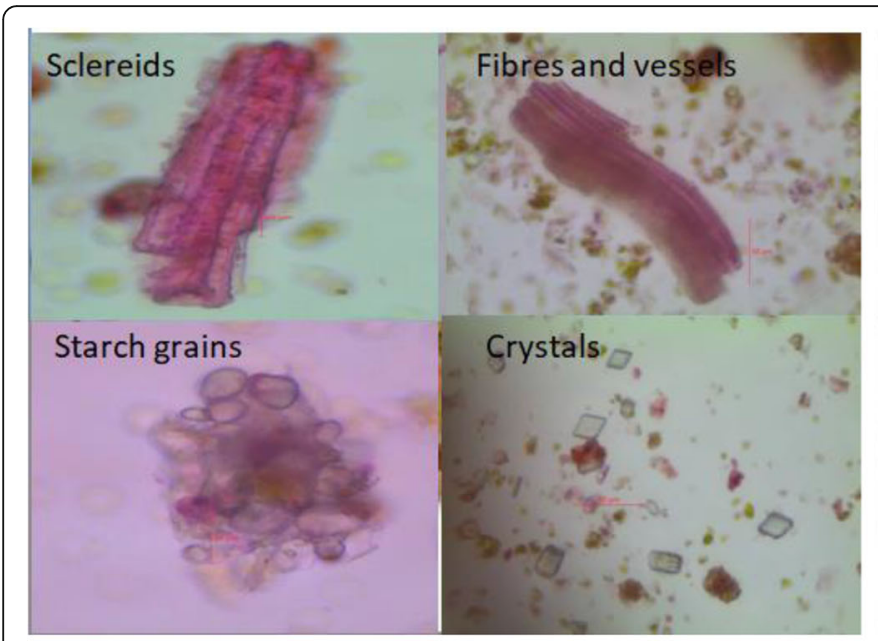

a

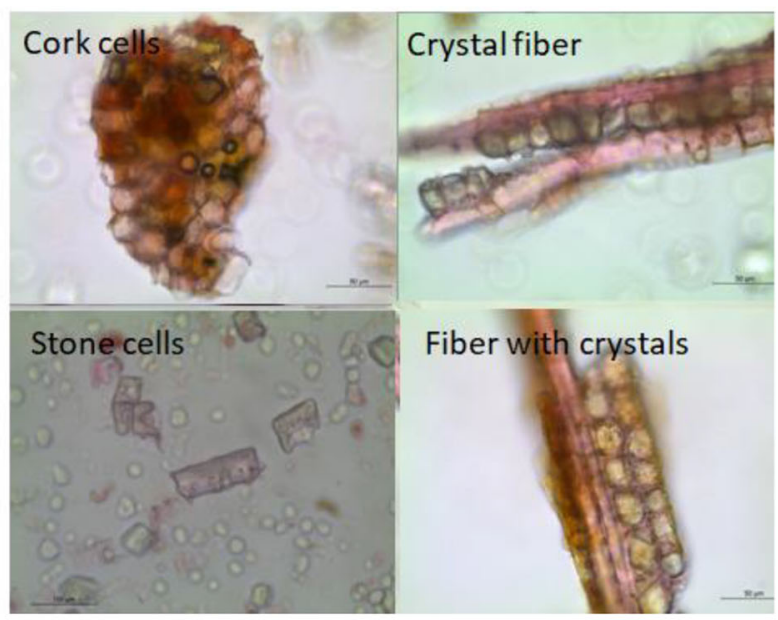

b

Fig. 7 Powder analysis of S. palghatense leaves (a) and bark (b)

isolated pooled fractions from methanol extract of leaves and bark of $S$. palghatense were added with reaction mixture $(10 \mu \mathrm{l}$ of $\mathrm{pH} 6.8$ phosphate buffer; $490 \mu \mathrm{l}$ of 5 $\mathrm{mM}$ p-nitro phenyl $\alpha$-d glucopyranoside (p-NPG)). The reaction mixture was incubated at $37{ }^{\circ} \mathrm{C}$ for $5 \mathrm{~min}$ then added $250 \mu \mathrm{l}$ of $\alpha$-glucosidase $(0.15 \mathrm{unit} / \mathrm{ml})$ and again incubated at $37{ }^{\circ} \mathrm{C}$ for $15 \mathrm{~min}$. Then reaction mixture was allowed to cool and added $2 \mathrm{ml}$ of sodium carbonate (200 $\mathrm{mM})$ to stop the reaction. The activity of enzyme inhibition was measured at $405 \mathrm{~nm}$ and acarbose was utilized as a reference compound.

\section{Percentage calculation}

Percentage of free radical scavenging and $\alpha$-amylase and $\alpha$-glucosidase inhibition was measured using the following formula: Percentage Inhibition/scavenging activity = $\left[\left(A_{\text {control }}-A_{\text {sample }}\right) /\left(A_{\text {control }}\right)\right] \times 100$. Where $A=$ absorbance.

\section{Results}

\section{Morpho-anatomical features}

S. palghatense is a small tree up to $15 \mathrm{~m}$ in height. The bark is smooth, grayish outside, and muddy brown within. The leaves are simple, opposite, or sub-opposite. Flowers are bisexual, white in terminal or axillary cymes. The leaf has plano-convex midrib and smooth lamina. The vascular strand consists of an arc of collateral xylem-phloem tissues. The xylem consists of elliptical thick-walled and lignified cells. The stomata are tetracytic or pentacytic (cyclocytic). Some of the epidermal cells were modified into epidermal trichomes. The peculiar features of the epidermal cells are presence of several radiating cells, called rosette cells. The entire structure is called cicatrix. The calcium oxalate crystals are seen deposited along the veins. The crystals are prismatic type. The individual prismatic crystals are located in each cell and the crystals are in vertical row.

The bark is wide with rough and fissured surface and consists of very thick periderm, well-developed cortex, and wide secondary phloem. There is presence of lignified phelloid layers in the phellem region. It acts as dead portion of periderm and function as protective barriers. Secondary phloem is the major component of the bark and calcium oxalate crystals are abundantly seen in the phloem cells. Secondary phloem is differentiated into two different zones, collapsed phloem, and uncollapsed phloem. The crystals are prismatic in shape. They are

Table 1 Fluorescence analysis of S. palghatense leaves and bark

\begin{tabular}{|c|c|c|c|c|c|c|}
\hline \multirow{2}{*}{$\begin{array}{l}\text { S. palghatense } \\
\text { leaf and bark } \\
\text { powders treated with, }\end{array}$} & \multicolumn{2}{|c|}{$254 \mathrm{~nm}$ UV light } & \multicolumn{2}{|c|}{366 nm UV light } & \multicolumn{2}{|l|}{ Visible light } \\
\hline & Leaves & Bark & Leaves & Bark & Leaves & Bark \\
\hline Acetone & Dark & Dark & Bluish black & Bluish black & Dark green & Dark green \\
\hline Acetonitrile & Dark & Dark & Dark blue & Dark blue & Green & Green \\
\hline Methanol & Black & Black & Blackish blue & Blackish blue & Greenish black & Greenish black \\
\hline Distilled water & Black & Black & Bluish black & Bluish black & Blackish green & Blackish green \\
\hline
\end{tabular}


Table 2 Physicochemical analysis of S. palghatense leaves and bark

\begin{tabular}{lll}
\hline Parameters & \multicolumn{2}{l}{ Values } \\
\cline { 2 - 3 } & Leaves & Bark \\
\hline Total ash & $3.30 \%$ & $5.30 \%$ \\
Water soluble ash & $2.54 \%$ & $1.82 \%$ \\
Acid insoluble ash & $0.53 \%$ & $0.21 \%$ \\
Sulphated ash & $3.67 \%$ & $7.43 \%$ \\
Water soluble extract & $30.51 \%$ & $32.87 \%$ \\
Alcohol soluble extract & $31.86 \%$ & $32.43 \%$ \\
Petroleum ether extract & $17.87 \%$ & $10.51 \%$ \\
Ethyl acetate soluble extract & $13.72 \%$ & $8.11 \%$ \\
Crude fiber & $15.39 \%$ & $13.10 \%$ \\
Vitamin C & $6.19 \%$ & $\mathrm{Absent}$ \\
Calcium & $1.8 \%$ & $3.50 \%$ \\
Potassium & $0.52 \%$ & $0.31 \%$ \\
Sodium & $0.21 \%$ & $1.23 \%$ \\
Copper & $48.28 \mathrm{mg} / \mathrm{kg}$ & $49.23 \mathrm{mg} / \mathrm{kg}$ \\
Zinc & $10.82 \mathrm{mg} / \mathrm{kg}$ & $7.55 \mathrm{mg} / \mathrm{kg}$ \\
Manganese & $4.60 \mathrm{mg} / \mathrm{kg}$ & $2.55 \mathrm{mg} / \mathrm{kg}$ \\
\hline
\end{tabular}

mostly cuboidal in shape. They occur in ray parenchyma cells, phelloderm cells, and marginal cells of ray cells (Fig. 1, 2, 3, 4, 5, and 6).

\section{Powder analysis}

The powder analysis plays a significant role in identification of crude drug. These characters will help in the identification of right variety and search for adulterants. This is one of the simplest and cheapest methods to start with for establishing the correct identity of the source materials. It is useful for further pharmacological and therapeutic evaluation along with the standardization of plant material. In the present investigation, powder microscopic studies revealed the presence of stomata on epidermal cells, sclereids, fibers and vessels, starch grains, and crystals in leaves. In bark, septate fiber with starch grains, crystal fiber associated with starch grains, stone cells, fiber-associated crystals, fiber with starch grains, and sclereids were found (Fig. 7).

\section{Florescence analysis}

Various chemical constituents present in plant material exhibit fluorescence. In daylight, some fluoresce in the visible range. Many natural products that do not fluoresce in daylight develop fluorescence when exposed to ultraviolet light. Even though some compounds are not fluorescent, they can be transformed into fluorescent derivatives using various chemical reagents, enabling us to evaluate the quality of some crude drugs using fluorescence, which is the most significant parameter in pharmacognostical evaluation.

The leaves and bark of S. palghatense were analyzed for their fluorescent properties, and color variations were observed under visible and ultra-violet light. The results are presented in Table 1 . The fluorescence analysis of leaf and bark powder of S. palghatense showed dark (254 nm UV light) and bluish black (366 nm UV light) color when treated with acetone. Green color was observed in acetonitrile under visible light. Various colors like greenish black, bluish black, and dark green were also observed under different light conditions.

\section{Physicochemical analysis}

The physico-chemical values of leaves and bark of $S$. palghatense were studied and tabulated. The determination of ash value gives an idea of the sandy or earthy matter, the inorganic composition, and other impurities present along with the drug. The total ash value is useful to exclude drugs, which have been adulterated with chalk, lime, or calcium sulfate. It is a valuable test to verify the quality of drug and any variation in the composition may cause a change in the extractive values. Thus, it helps in the determination of exhausted or adulterated drugs. Both leaves and bark of $S$. palghatense show high nutritional values (Table 2).

\section{Phytochemical studies}

Methanolic and distilled water extracts of S. palghatense leaves and bark shows higher percentage of yield as compared to other solvent extracts (Table 3). In this study, the extractive values were observed to increase with increasing polarity of the solvent used.

Table 3 Percentage of yield of different extracts of S. palghatense leaves and bark

\begin{tabular}{|c|c|c|c|c|c|}
\hline \multirow[t]{2}{*}{ Solvents } & \multirow{2}{*}{$\begin{array}{l}\text { Weight } \\
\text { of plant } \\
\text { material (g) }\end{array}$} & \multicolumn{2}{|c|}{ Color of extract } & \multirow{2}{*}{$\begin{array}{l}\text { Weight of } \\
\text { dried extract (g) }\end{array}$} & \multirow{2}{*}{$\begin{array}{l}\text { Extractive } \\
\text { value (\%) }\end{array}$} \\
\hline & & Leaves & Bark & & \\
\hline Chloroform & 20 & Light green & Light brown & 0.2 & 1 \\
\hline Ethyl acetate & 20 & Pale green & Light yellow & 0.28 & 1.4 \\
\hline Methanol & 20 & Dark green & Brownish yellow & 4.5 & 22.5 \\
\hline Distilled water & 20 & Dark green & Dark brown & 4.8 & 24 \\
\hline
\end{tabular}


Table 4 Phytoconstituents present in the different solvent extracts of S. palghatense leaves and bark

\begin{tabular}{|c|c|c|c|c|c|c|c|c|}
\hline \multirow{3}{*}{$\begin{array}{l}\text { Qualitative } \\
\text { analysis }\end{array}$} & \multicolumn{8}{|c|}{ Solvent extracts } \\
\hline & \multicolumn{2}{|c|}{ Chloroform } & \multicolumn{2}{|c|}{ Ethyl acetate } & \multicolumn{2}{|c|}{ Methanol } & \multicolumn{2}{|c|}{ Distilled water } \\
\hline & SPL & SPB & SPL & SPB & SPL & SPB & SPL & SPB \\
\hline Alkaloids & - & - & - & - & + & + & + & + \\
\hline Flavonoids & - & - & - & - & - & - & - & - \\
\hline Glycoside & - & - & - & - & + & + & - & - \\
\hline Saponins & - & - & - & - & - & - & + & + \\
\hline Carbohydrate & - & - & - & - & + & + & + & + \\
\hline Tannin & - & - & - & - & + & + & + & + \\
\hline Reducing sugar & - & - & - & - & + & + & + & + \\
\hline Starch & - & - & - & - & - & - & - & - \\
\hline Phenolics & - & - & - & - & + & + & + & + \\
\hline Anthraquinone & - & - & - & - & - & - & - & - \\
\hline Fatty oil & - & - & - & - & - & - & - & - \\
\hline Essential oil & + & + & + & + & + & + & + & + \\
\hline Proteins & - & - & - & - & - & - & - & - \\
\hline Amino acids & - & - & - & - & - & - & - & - \\
\hline Steroids & - & - & - & - & - & - & - & - \\
\hline Coumarin & - & - & - & - & - & - & - & - \\
\hline
\end{tabular}

SPL Syzygium palghatense leaves, SPB Syzygium palghatense bark; -: Absent; +: Present

\section{Qualitative analysis}

Methanolic and distilled water extracts of both leaves and bark of S. palghatense contains more phytoconstituents as compared to chloroform and ethyl acetate extracts (Table 4). The essential oil, alkaloid, glycosides, carbohydrate, tannins, reducing sugar, and phenolics were present in both methanol and distilled water extracts of S. palghatense. Saponin present in distilled water extracts of leaves and bark of $S$. palghatense.

\section{Quantitative analysis}

S. palghatense leaves and bark contain significant amount of phytoconstituents (Table 5). Methanol extracts of leaves of $S$. palghatense contain $128.8 \mu \mathrm{g} / \mathrm{mg}$ alkaloid, $180 \mu \mathrm{g} / \mathrm{mg}$ flavonoids, $318.5 \mu \mathrm{g} / \mathrm{mg}$ glycosides, and $237.4 \mu \mathrm{g} / \mathrm{mg}$ tannin. Bark contains $130 \mathrm{mg} / \mathrm{g}$ total carbohydrates. Both leaves and bark of plant have higher amount of phytoconstituents in the methanol and distilled water extracts.

\section{Antioxidant activity}

Leaves and bark of S. palghatense shows scavenging effects toward DPPH, hydroxyl, and superoxide radicals. A significant activity was also found in the ferric-reducing antioxidant power assay. The scavenging compounds were expressed in terms of its hydrogen donating ability. In DPPH assay, a dosedependent scavenging activity was observed in the

Table 5 Quantitative amount of phytoconstituents present in the leaves and bark of S. palghatense

\begin{tabular}{|c|c|c|c|c|}
\hline \multirow[t]{2}{*}{ Parameters } & \multicolumn{2}{|c|}{ Leaves ( $\mu \mathrm{g} / \mathrm{mg}$ gallic acid equivalent) } & \multicolumn{2}{|c|}{ Bark ( $\mu \mathrm{g} / \mathrm{mg}$ gallic acid equivalent) } \\
\hline & Methanol & Distilled water & Methanol & Distilled water \\
\hline Alkaloids & $128.8 \mu \mathrm{g} / \mathrm{mg}$ & $88.8 \mu \mathrm{g} / \mathrm{mg}$ & $40 \mu \mathrm{g} / \mathrm{mg}$ & $177.7 \mu \mathrm{g} / \mathrm{mg}$ \\
\hline Flavonoids & $180 \mu \mathrm{g} / \mathrm{mg}$ & $146.25 \mu \mathrm{g} / \mathrm{mg}$ & $141.25 \mu \mathrm{g} / \mathrm{mg}$ & $61.25 \mu \mathrm{g} / \mathrm{mg}$ \\
\hline Glycosides & $318.5 \mu \mathrm{g} / \mathrm{mg}$ & $234.5 \mu \mathrm{g} / \mathrm{mg}$ & $147.5 \mu \mathrm{g} / \mathrm{mg}$ & $123 \mu \mathrm{g} / \mathrm{mg}$ \\
\hline Saponin & & $145.5 \mu \mathrm{g} / \mathrm{mg}$ & & $42.25 \mu \mathrm{g} / \mathrm{mg}$ \\
\hline Total carbohydrate & $81.25 \mathrm{mg} / \mathrm{g}$ & & $130 \mathrm{mg} / \mathrm{g}$ & \\
\hline Tannin & $237.4 \mu \mathrm{g} / \mathrm{mg}$ & $250 \mu \mathrm{g} / \mathrm{mg}$ & $186.5 \mu \mathrm{g} / \mathrm{mg}$ & $130 \mu \mathrm{g} / \mathrm{mg}$ \\
\hline Reducing sugar & $2.8 \mathrm{mg} / \mathrm{g}$ & & $4.77 \mathrm{mg} / \mathrm{g}$ & \\
\hline Phenol & $100.3 \mu \mathrm{g} / \mathrm{mg}$ & $100.5 \mu \mathrm{g} / \mathrm{mg}$ & $86 \mu \mathrm{g} / \mathrm{mg}$ & $80.4 \mu \mathrm{g} / \mathrm{mg}$ \\
\hline
\end{tabular}


Table 6 DPPH radical reducing activity of different solvent extracts of S. palghatense leaves and bark

\begin{tabular}{lll}
\hline Solvent & \multicolumn{2}{l}{ DPPH radical scavenging activity $\left(\mathrm{IC}_{\mathbf{5 0}}\right) \boldsymbol{\mu g} \mathbf{g} \mathbf{m l}$} \\
\cline { 2 - 3 } extracts & S. palghatense leaves & S. palghatense bark \\
\hline Chloroform & No activity & No activity \\
Ethyl acetate & $12.5 \pm 0.7071$ & $76 \pm 1.044$ \\
Distilled water & $2.75 \pm 0.07$ & $8 \pm 1.080$ \\
Methanol & $1.625 \pm 0.035$ & $4.45 \pm 0.0707$ \\
\hline
\end{tabular}

$I_{50}$ inhibitory concentration at $50 \%$; values are mean \pm standard deviation (SD)

range of $1-5 \mu \mathrm{g} / \mathrm{ml}$ of the methanol extract of both leaves and bark of the S. palghatense. Due to the significant inhibition of methanol extracts of both leaves and bark of the S. palghatense, it was taken for the further biological activities instead of other solvents (Table 6).

Methanoic extracts of both leaves and bark of $S$. palghatense shows significant results in the superoxide radical scavenging assay, hydroxyl radical scavenging activity, and ferric-reducing antioxidant power assay as compared to chloroform, ethyl acetate, and distilled water extracts (Figs. 8, 9, 10, 11, and 12). The $\mathrm{IC}_{50}$ value of the methanolic extract of leaves in DPPH, superoxide radical scavenging assay, hydroxyl radical scavenging activity, and ferricreducing antioxidant power assay was estimated to be $1.625 \pm 0.035,52 \pm 0.375,62 \pm 1.821$, and 2.737 $\pm 0.06 \mu \mathrm{g} / \mathrm{ml}$ respectively and in bark $4.45 \pm 0.0707$, $63 \pm 1.414,64 \pm 1.29$, and $2.407 \pm 0.049 \mu \mathrm{g} / \mathrm{ml}$ respectively.

\section{Anti-diabetic activity}

In alpha amylase and alpha glucosidase inhibitory assay, significant activity was found in both leaves and bark of S. palghatense (Tables 7 and 8). Percentage of inhibition was increasing according to the concentration of solvents used. This shows that the plant possess significant anti-diabetic activity. Methanolic extracts of both leaves and bark of S. palghatense exhibited $91.27 \pm 0.58$ and $86.46 \pm 0.65$ percentage of inhibition, respectively in alpha amylase inhibitory assay. In alpha glucosidase inhibitory assay, it shows $87.47 \pm 0.40$ and $82.57 \pm 0.42$ percentages of inhibition in leaves and bark of S. palghatense respectively.

\section{Discussion}

Pharmacognostical and phytochemical analysis of the leaves and bark of Syzygium cumini were studied by different scientists and reported that Syzygium has various medicinal properties [37]. But there are no reports in the literature on the bioactive screening and pharmacognostic efficacy of the $S$. palghatense, which is endemic to Western Ghats. Thus, present study is the first report on this plant and unraveling the pharmacognostic studies of S. palghatense.

Morpho-anatomical studies of the plant provided an insight into the constructive information with regards to the identification. Both leaves and bark of S. palghatense have peculiar features in their plant parts, which differentiate this plant from other species of Syzygium.

S. palghatense also shares common anatomical characters with other Myrtaceae. Some of these features include the presence of calcium oxalate crystals, internal

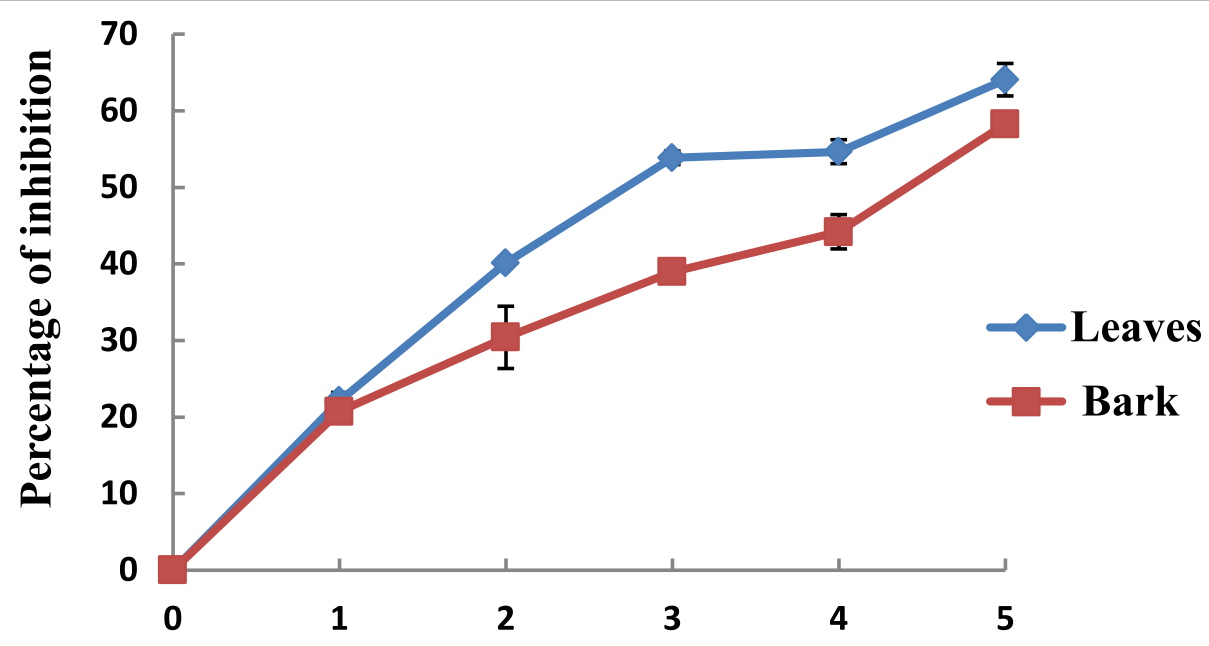

Concentration $\mu \mathrm{g} / \mu \mathrm{l}$

Fig. 8 DPPH radical reducing activity of methanol extracts of S. palghatense leaves and bark. Error bars represent the standard error of observed data in all six replications 


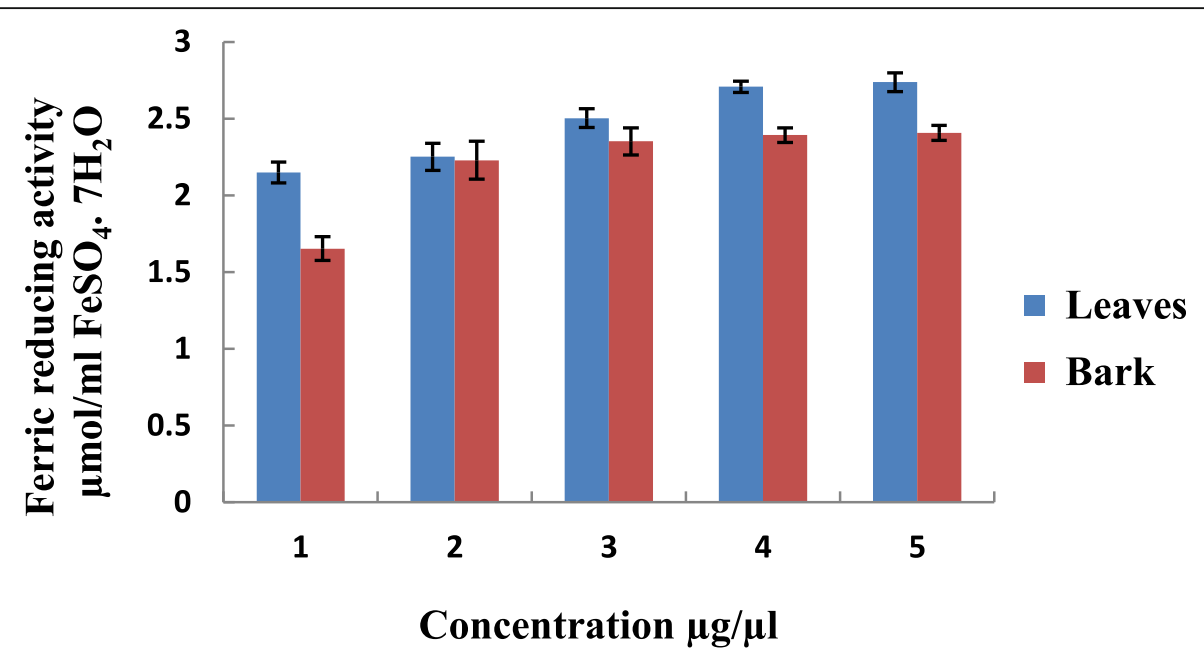

Fig. 9 Ferric reducing antioxidant power activity of S. palghatense leaves and bark. Error bars represent the standard error of observed data in all six replications

phloem, and schizogenous secretory cavities. Anatomical characters described here largely agree with other species of Syzygium [38]. The function of calcium oxalate crystals is not completely clear, but has been related to the regulation of calcium and other minerals [39] as well as protection against herbivores and pathogens [40, 41].

Powder microscopic studies revealed the quality of leaves and bark of the S. palghatense and it can be used for the further drug development. Some chemical constituents present in the extracts shows fluorescent character under ordinary light and some other chemical constituents present in the extracts were responsible for the fluorescence character under ultraviolet light. The fluorescent analysis of powdered drugs is crucial for evaluating the drug's quality and purity.

Physico-chemical properties of the plant sample helps in the determination of adulterated drugs. In the present investigation, S. palghatense exhibited higher nutritional value. Similar studies were carried out in S. cumini [42]. Phytochemicals such as flavonoids, phenols, and $\beta$ carotene are present in food that we daily intake. The combined action of phytochemicals through a variety of mechanism may induce antioxidant capacity. Phenolics compounds are powerful donors of hydrogen, which make them good antioxidants $[43,44]$ and are largest found compounds which is widely distributed

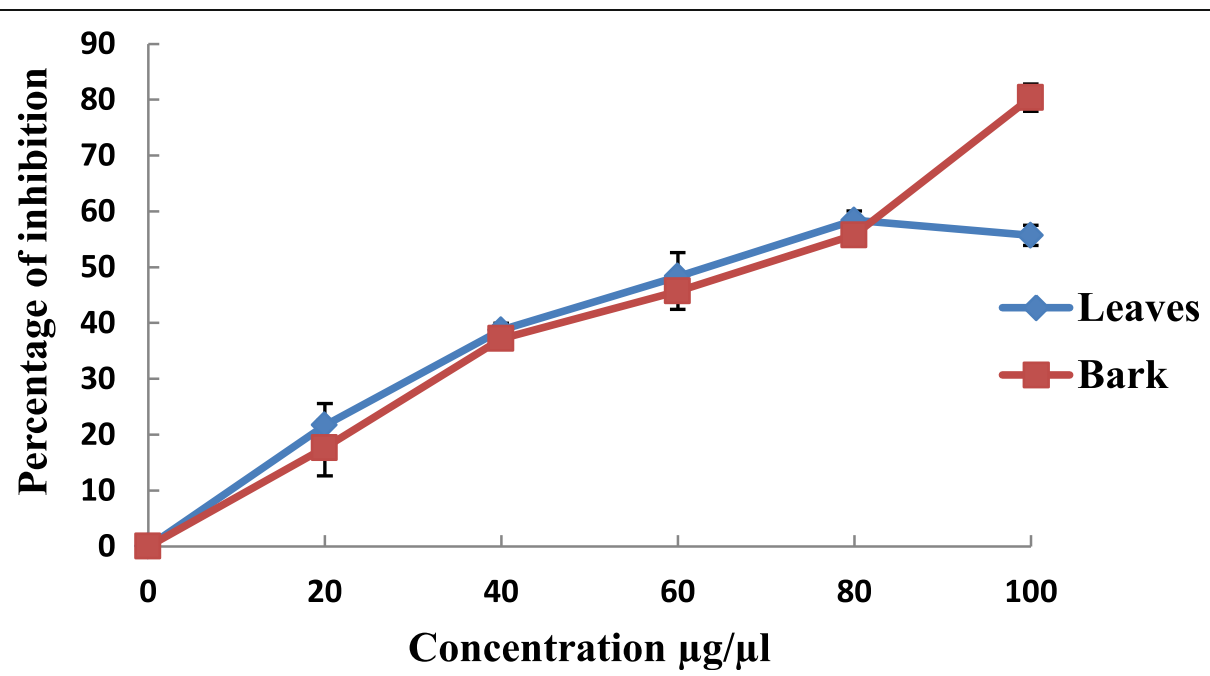

Fig. 10 Hydroxyl radical scavenging activity of S. palghatense leaves and bark. Error bars represent the standard error of observed data in all six replications 


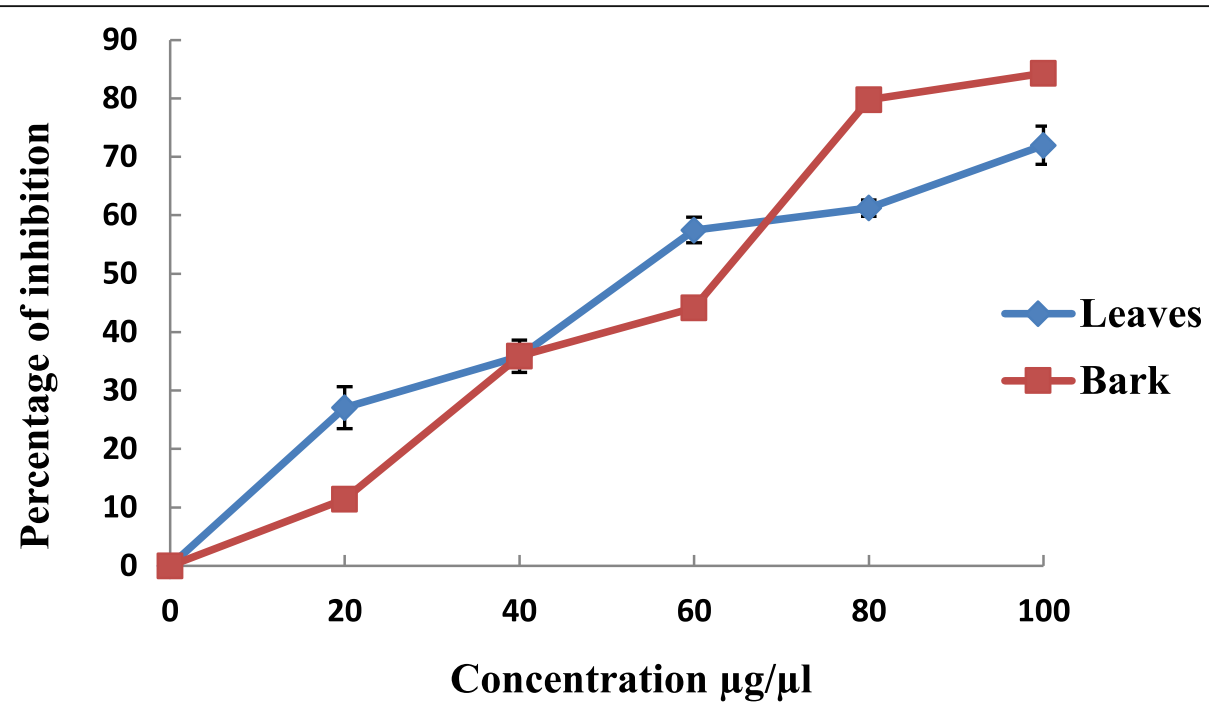

Fig. 11 Inhibition of superoxide radicals-riboflavin photoreduction method of S. palghatense leaves and bark. Error bars represent the standard error of observed data in all six replications

phytochemical of plants. In the present study, the phenolic content of the methanolic extract of $S$. palghatense leaves and bark were 100.03 and $86 \mu \mathrm{g} / \mathrm{mg}$ gallic acid equivalent respectively. The result reveals that $S$. palghatense bear high phenolic content and that may the reason behind its antioxidant activity. Saponins are groups of secondary metabolites found in plants and regarded as high molecular weight compounds. Saponins were found to present in aqueous extracts of leaves and bark of $S$. palghatense. Alkaloids are natural products that contain heterocyclic nitrogen atoms which have significant role in protection and survival of plant [45]. Alkaloids were found to be present in both methanol and distilled water extracts of leaves and bark of $S$. palghatense.

A positive correlation was observed between total antioxidant activity and total phenolic contents. The plants with high antioxidant and antidiabetic potential have increased amount of polyphenols [46, 47]. The antioxidant property of the Syzygium species may come in part from the antioxidant vitamins, phenolics, tannins, and anthocyanin compounds present in the plant parts. The

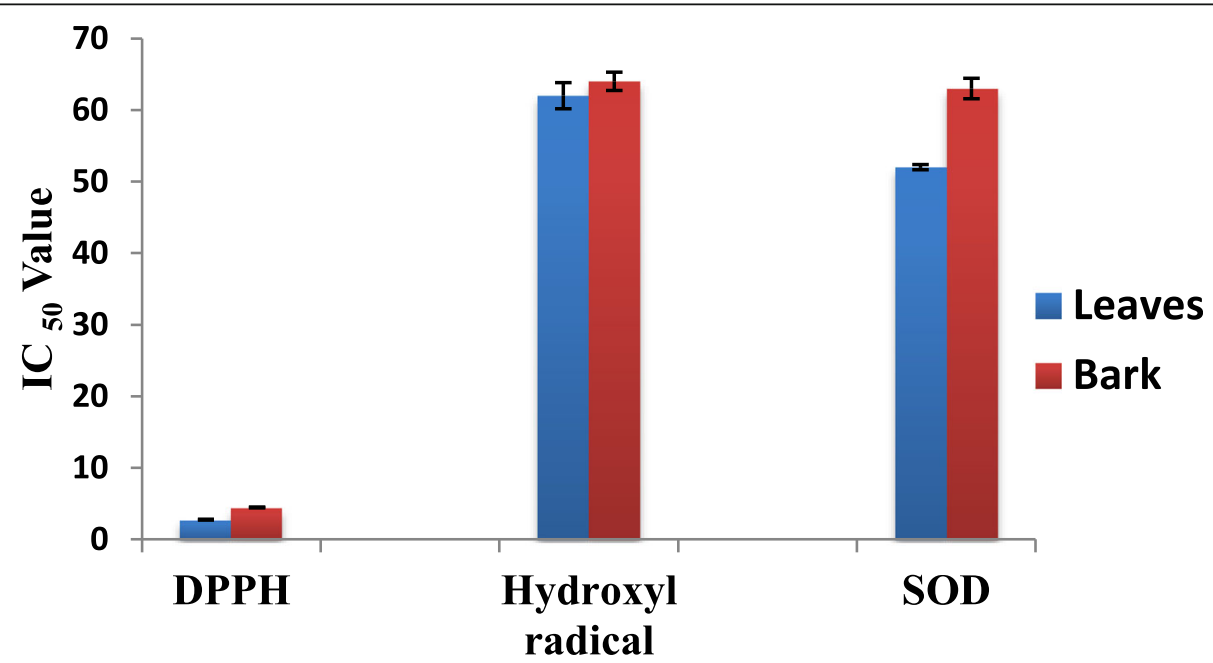

Fig. $12 I_{50}$ value of the S. palghatense leaves and bark in DPPH radical scavenging assay, hydroxyl radical scavenging activity, and superoxide radical scavenging assay 
Table 7 Alpha amylase inhibitory assay of S. palghatense leaves and bark

\begin{tabular}{lll}
\hline $\begin{array}{l}\text { Concentration } \\
(\boldsymbol{\mu g} / \boldsymbol{\mu l})\end{array}$ & \multicolumn{2}{l}{ Percentage of inhibition (\%) } \\
\cline { 2 - 3 } & Leaves & Bark \\
\hline 20 & $38.46 \pm 1.02$ & $35.46 \pm 1.00$ \\
40 & $49.15 \pm 0.81$ & $46.61 \pm 0.89$ \\
60 & $61.44 \pm 0.75$ & $59.46 \pm 0.76$ \\
80 & $82.03 \pm 0.69$ & $75.33 \pm 0.71$ \\
100 & $91.27 \pm 0.58$ & $86.46 \pm 0.65$ \\
\hline
\end{tabular}

Values are mean \pm standard deviation (SD)

observations from the present investigation confirm the medicinal use of $S$. palghatense leaves and bark extracts as a natural antioxidant and justify the ethnobotanical approach in the search for novel bioactive compounds. Syzygium species which have a high alpha glucosidase inhibitory activity are S. cumini and S. syzygoides [48]. The leaves of S. cumini significantly inhibited the alpha amylase in a dose dependant manner [49]. Similar results were noticed in the present investigation.

In the present study, potentiality of the plant is due to the presence of alkaloid, tannin, flavonoids, phenols, and other phytoconstituents present in the leaves and bark of S. palghatense.

\section{Conclusion}

The first step in determining the identification and degree of purity of herbal materials is to conduct pharmacognostic studies. Morpho-anatomical characteristics, physicochemical analysis, powder characteristics, fluorescence analysis, and antioxidant and antidiabetic potential of $S$. palghatense leaves and bark were listed in the current study. This pharmacognostic studies has never been published before in this plant species, making this the first report to include an extensive pharmacognostic profile of $S$. palghatense, which will aid in the proper identification and authentication of the species for future research. The current study discovered that the methanolic extract of $S$. palghatense leaves and bark has pharmacognostic properties as well as potential antioxidant and anti-diabetic compounds. The presence of several

Table 8 Alpha glucosidase inhibitory assay of S. palghatense leaves and bark

\begin{tabular}{lll}
\hline $\begin{array}{l}\text { Concentration } \\
(\boldsymbol{\mu g} / \boldsymbol{\mu l})\end{array}$ & \multicolumn{2}{l}{ Percentage of inhibition (\%) } \\
\cline { 2 - 3 } & Leaves & Bark \\
\hline 20 & $37.50 \pm 0.74$ & $33.46 \pm 0.80$ \\
40 & $45.36 \pm 0.67$ & $44.21 \pm 0.71$ \\
60 & $54.84 \pm 0.51$ & $52.16 \pm 0.69$ \\
80 & $68.62 \pm 0.48$ & $64.31 \pm 0.54$ \\
100 & $87.47 \pm 0.40$ & $82.57 \pm 0.42$ \\
\hline
\end{tabular}

Values are mean \pm standard deviation (SD) biologically active secondary metabolites, including essential oil, alkaloid, glycosides, carbohydrate, tannins, reducing sugar, phenolics, and saponins, which may be the reason for its biological properties. As compared to bark, leaves of $S$. palghatense possess significant activity toward all the biological properties.

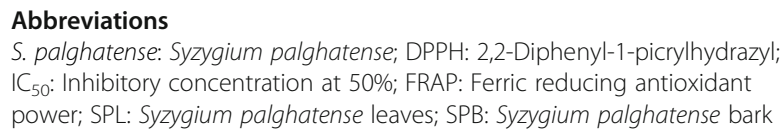

\section{Acknowledgements}

The authors are grateful to Govt. Victoria College, Palakkad for the laboratory facilities and Forest Department, Govt. of Kerala, India for the forest permission to collect samples.

\section{Authentication of plant material}

The plant material was identified and authenticated by Dr. P. Sujanapal, Scientist, Silviculture Department, Kerala Forest Research Institute, Peechi, Thrissur and Dr. A.K. Pradeep, Assistant Professor, Department of Botany, University of Calicut. The voucher specimen was deposited in the Calicut University Herbarium, Department of Botany, with accession number 7054.

\section{Permission for plant collection and study}

The authors procured permission from the Forest Department, Govt. of Kerala, India to visit and collect the plant sample from the forest areas for the research purposes as per the Order No. WL10-1497/2018 Dated 01.08.2018 and accordingly procured the sample for study.

\section{Authors' contributions}

Authors' were involved in the conceptualization of the experiment. ARR designed and executed the work. VRS performed experimental works and data compilation. All authors have read and approved the manuscript.

\section{Funding}

Not applicable.

\section{Availability of data and materials}

The data used to support the findings of this study are available from the corresponding author upon request.

\section{Declarations}

Ethics approval and consent to participate

Not applicable. This research article does not contain any studies using animals or human.

\section{Consent for publication}

Not applicable.

\section{Competing interests}

The authors declare that they have no competing interests.

Received: 9 March 2021 Accepted: 14 June 2021

Published online: 22 July 2021

References

1. Yesodharan K, Mohanadas K, Chandrasekhara Pillai PK (2009) Conservation of the critically endangered tree Syzygium palghatense Gamble (Myrtaceae), in the Western Ghats of Kerala. KFRI project No 428/2004. KFRI project report no. 318.

2. Yen GC, Duh PD, Tsai CL (1993) Relationship between antioxidant activity and maturity of peanut hulls. J Agric Food Chem 41(1):67-70. https://doi. org/10.1021/jf00025a015

3. Sass JE (1940) Elements of botanical microtechnique. McGraw Hill Book Co., New York, p 222

4. O'Brien TP, Feder N, McCull ME (1964) Polychromatic staining of plant cell walls by toluidine blue-o. Protoplasma 59:364-373 
5. Anonymous (2008) The Ayurvedic Pharmacopoeia of India. Ayush, Govt. of India, Ministry of Health and Family Welfare, New Delhi

6. Tandon N, Sharma P (2017) Quality standards of Indian medicinal plants, vol 15. Medicinal Plants Division, Indian Council of Medical Research, New Delhi, pp 371-372

7. Kokashi CJ, Kokashi RJ, Sharma M (1958) Fluorescence of powdered vegetable drugs in Ultra-Violet radiation. J Am Pharm Assoc 47:715-717

8. Gupta MK, Sharma PK, Ansari SH, Lagarkha R (2006) Pharmacognostical evaluation of Grewia asiatica fruits. Int J Plant Sci 1(2):249-251

9. Sharma A, Sharma AK, Chand T, Khardiya M, Yadav KC (2013) Preliminary phytochemical evaluation of seed extracts of Cucurbita maxima Duchense. J Pharmacog Phytochem 2(3):62-65

10. Bigoniya P, Singh CS, Srivastava B (2012) Pharmacognostical and physicochemical standardization of Syzygium cumini and Azadirachta indica seed. Asian Pac J Trop Biomed 2(1):S290-S295. https://doi.org/10.1016/S2221-1691 (12)60176-2

11. Sasmal S, Majumdar S, Gupta M, Mukherjee A, Mukherjee PK (2012) Pharmacognostical, phytochemical and pharmacological evaluation for the antipyretic effect of the seeds of Saraca asoca Roxb. Asian Pac J Trop Biomed 2(10):782-786. https://doi.org/10.1016/S2221-1691(12)60229-9

12. Anonymous (1996) Pharmacopoeia of India, 2nd edn. Manager of Publications, New Delhi, pp 947-948

13. Mulla SK, Paramjyothi S (2010) Preliminary pharmacognostical and phytochemical evaluation of Portulaca quadrifida Linn. Int J Pharm Tech Res 2(3):1699-1702 https://www.cabdirect.org/cabdirect/abstract/20103248548

14. Bhattacharya S, Zaman MK (2009) Pharmacognostical evaluation of Zanthoxylum nitidum bark. Int J Pharm Tech Res 1(2):292-298

15. Kumar D, Gupta J, Kumar S, Arya R, Kumar T, Gupta A (2012) Pharmacognostic evaluation of Cayratia trifolia (Linn.) leaf. Asian Pac J Trop Biomed 2(1):6-10. https://doi.org/10.1016/S2221-1691(11)60180-9

16. Harborne (1999) Phytochemical dictionary: Handbook of bioactive compounds from plants, 2nd edn

17. Morsy N (2014) Phytochemical analysis of biologically active constituents of medicinal plants. Main Group Chem 13(1):7-21. https://doi.org/10.3233/ MGC130117

18. Santhi KS, Sengottuvel R (2016) Qualitative and quantitative phytochemica analysis of Moringa concanensis Nimmo. Int J Curr Microbiol Appl Sci 5(1): 633-640. https://doi.org/10.20546/ijcmas.2016.501.064

19. Gul R, Jan SU, Faridullah S, Sherani S, Jahan N (2017) Preliminary phytochemical screening, quantitative analysis of alkaloids, and antioxidant activity of crude plant extracts from Ephedra intermedia Indigenous to Balochistan [Research Article]. Sci World J. https://doi.org/10.1155/2017/5873 648

20. Sofowora A (1993) Screening plants for bioactive agents. In: Medicinal plants and traditional medicinal in Africa, 2nd edn. Spectrum Books Ltd, Sunshine House, Ibadan, pp 134-156

21. Vishnoi NR (1979) Advanced Practical Chemistry. Yikas Publication House, PVT Ltd., Ghaziabad-India, pp 447-449

22. Boxi M, Rajesh Y, Raja Kumar V, Praveen B, Mangamma K (2010) Extraction, phytochemical screening and in vitro evaluation of anti-oxidant properties of Commicarpus chinesis (aqueous leaf extract). Int J Pharm Biosci 1:537-547

23. Harborne AJ (1998) Phytochemical methods a guide to modern techniques of plant analysis, 3rd edn. Springer, Netherlands https://www.springer.com/ gp/book/9780412572609. Accessed 5 Sept 2019

24. Har LW, Ismail IS (2012) Antioxidant activity, total phenolics and total flavonoids of Syzygium polyanthum (Wight) Walp leaves. Int J Med Arom Plants 2(2):219-228

25. Solich P, Sedliakova V, Karlicek R (1992) Spectrophotometric determination of cardiac glycosides by flow-injection analysis. Anal Chim Acta 269(2):199203. https://doi.org/10.1016/0003-2670(92)85403-S

26. Khanna VG, Kannabiran K, Getti G (2009) Leishmanicidal activity of saponins isolated from the leaves of Eclipta prostrata and Gymnema sylvestre. Indian J Pharmacol 41(1):32-35. https://doi.org/10.4103/0253-7613.48891

27. Hedge JE, Hofreiter BT (1962) In: Whistler RL, Miller JN (eds) Carbohydrate chemistry. Academic, New York, p 17

28. Kavitha Chandran Cl, Indira G (2016) Quantitative estimation of total phenolic, flavonoids, tannin and chlorophyll content of leaves of Strobilanthes Kunthiana (Neelakurinji). J Med Plants Stud 4(4):282-286

29. Miller GL (1959) Use of Dinitrosalicylic acid reagent for determination of reducing sugar. Anal Chem 31(3):426-428. https://doi.org/10.1021/ac60147a 030
30. Samidha K, Vrushali K, Vijaya P (2014) Estimation of phenolic content, flavonoid content, antioxidant and alpha amylase inhibitory activity of marketed polyherbal formulation. J App Pharm Sci 4(9):61-065

31. Aquino R, Morelli S, Lauro MR, Abdo S, Saija A, Tomaino A (2001) Phenolic constituents and antioxidant activity of an extract of Anthurium versicular leaves. J Nat Prod 64(8):1019-1023. https://doi.org/10.1021/np0101245

32. Mc Cord JM, Fridovich I (1969) Superoxide dismutase enzyme function for erythrocaprein. J Biochem 244:6049-6056

33. Saldanha LA, Elias G, Rao MN (1990) Oxygen radical scavenging activity of phenylbutenones and their correlation with anti-inflammatory activity. Arzneimittel forschung 40(1):89-91

34. Pulido R, Bravo L, Saura-Calixto F (2000) Antioxidant activity of dietary polyphenols as determined by a modified ferric reducing/antioxidant power assay. J Agric Food Chem 48(8):3396-3042. https://doi.org/10.1021/jf99134 58

35. Hansawasdi C, Kawabata J, Kasai T (2000) a-Amylase inhibitors from roselle (Hibiscus sabdariffa Linn.) tea. Biosci Biotechnol Biochem 64(5):1041-1043. https://doi.org/10.1271/bbb.64.1041

36. Yin Z, Zhang W, Feng F, Zhang Y, Kang W (2014) a-Glucosidase inhibitors isolated from medicinal plants. Food Sci Hum Wellness 3(3-4):136-174. https://doi.org/10.1016/j.fshw.2014.11.003

37. Korth K, Doege S, Park S, Goggin F, Wang Q, Gomez S, Liu G, Jia L, Nakata P (2006) Medicago truncatula mutants demonstrate the role of plant calcium oxalate crystals as an effective defense against chewing insects. Plant Physiol 141(1):188-195. https://doi.org/10.1104/pp.106.076737

38. Soh W, Parnell J (2011) Comparative leaf anatomy and phylogeny of Syzygium Gaertn. Plant Syst Evol 297(1-2):1-32. https://doi.org/10.1007/ s00606-011-0495-2

39. Volk G, Lynch--Holm V, Kostman T, Goss L, Franceschi V (2002) The role of druse and raphide calcium oxalate crystals in tissue calcium regulation in Pistia stratiotes leaves. Plant Bio 4(1):34-45. https://doi.org/10.1055/s-2002-2 0434

40. Franceschi VR, Nakata P (2005) Calcium oxalate in plants: formation and function. Annu Rev Plant Biol 56(1):41-71. https://doi.org/10.1146/annurev.a rplant.56.032604.144106

41. Shanthi S, Maddali R, Fatima Grace X, Alekya PT, Latha S, Chamundeeswari D (2014) Pharmacognostical and preliminary phytochemical studies on stem bark of Eugenia jambolana. Int J Pharm Sci Rev Res 29(1):74-76

42. Ghosh P, Pradhan RC, Mishra S, Patel AS, Kar A (2017) Physicochemical and nutritional characterization of Jamun (Syzygium Cumini). Curr Res Nutr Food Sci 5(1):25-35. https://doi.org/10.12944/CRNFSJ.5.1.04

43. Chen W, Zhu Q, Xia Q, Cao W, Zhao S, Liu J (2011) Relative oxygen species scavenging activity and DNA protecting effect of fresh and naturally fermented coconut sap. J Food Bio 35(5):1381-1388. https://doi.org/1 $0.1111 / j .1745-4514.2010 .00506 . x$

44. Gowri SS, Vasantha K (2010) Phytochemical screening and antibacterial activity of Syzygium cumini (L.) (Myrtaceae) leaves extracts. Inter J Pham Tech Res 2(2):1569-1573

45. Kumar A, Liavarasan $R$, Jayachandran $T$, Decaraman $M$, Aravindhan $P$, Padmanabhan N, Krishan MRV (2009) Phytochemicals investigation on a tropical plant, Syzygium cumini from Kattuppalayam, Erode District, Tamil Nadu, South India. Pak J Nutri 8(1):83-85

46. Gudise V, Chowdhury B, Manjappa AS (2019) In vitro free radical scavenging and antidiabetic activity of aqueous and ethanolic leaf extracts: a comparative evaluation of Argyreia pierreana and Matelead enticulata. Future J Pharm Sci 5(1):1-1. https://doi.org/10.1186/s43094-019-0014-9

47. Ravi K, Ramachandran B, Subramanian S (2004) Effect of Eugenia jambolana seed kernel on antioxidant defense system in streptozotocin induced diabetes in rats. Life Sci 75(22):2717-2273. https://doi.org/10.1016/j.lfs.2004. 08.005

48. Saraswaty V (2010) Alpha glucosidase inhibitory activity from Syzigium sp. Teknologi Indonesia 33(1):33-37

49. Jha AN, Bartariya G, Kumar A (2018) Qualitative analysis and a-amylase inhibition assay of aqueous foliar extract of Syzygium cumini (L.). Indo American J Pharm Sci 5(2):973-997

\section{Publisher's Note}

Springer Nature remains neutral with regard to jurisdictional claims in published maps and institutional affiliations. 